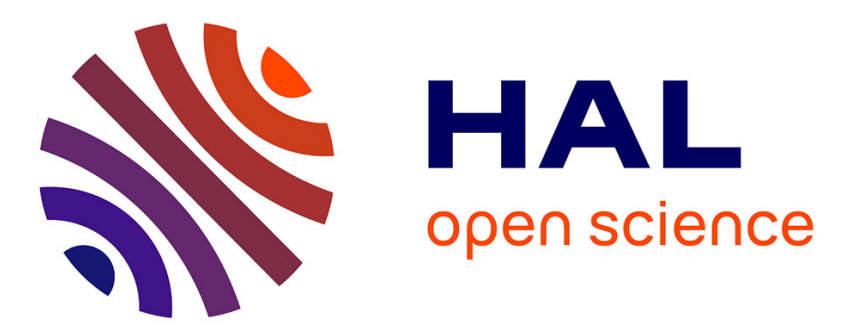

\title{
Rootstock effects on the reaction of grafted cypress to it Seiridium cardinale bark canker disease
}

\author{
Alberto Santini, Paolo Raddi, Alberto Panconesi, Vincenzo Di Lonardo
}

\section{To cite this version:}

Alberto Santini, Paolo Raddi, Alberto Panconesi, Vincenzo Di Lonardo. Rootstock effects on the reaction of grafted cypress to it Seiridium cardinale bark canker disease. Agronomie, 2000, 20 (3), pp.325-331. 10.1051/agro:2000130 . hal-00886014

\section{HAL Id: hal-00886014 https://hal.science/hal-00886014}

Submitted on 1 Jan 2000

HAL is a multi-disciplinary open access archive for the deposit and dissemination of scientific research documents, whether they are published or not. The documents may come from teaching and research institutions in France or abroad, or from public or private research centers.
L'archive ouverte pluridisciplinaire HAL, est destinée au dépôt et à la diffusion de documents scientifiques de niveau recherche, publiés ou non, émanant des établissements d'enseignement et de recherche français ou étrangers, des laboratoires publics ou privés. 


\title{
Rootstock effects on the reaction of grafted cypress to Seiridium cardinale bark canker disease
}

\author{
Alberto Santini*, Paolo RAdDI, Alberto PANCONESi, Vincenzo Di LonARDo \\ Istituto per la Patologia degli Alberi Forestali, CNR, Piazzale delle Cascine 28, 50144 Florence, Italy
}

(Received 19 July 1999; accepted 11 January 2000)

\begin{abstract}
Knowledge of rootstock effects on the reaction of grafted cypresses to bark canker disease induced by Seiridium cardinale, as well as a knowledge of cypress growth parameters, could play an important role in the production of resistant clones. Auto-, homo- and heteroplastic grafts were carried out by using self-rooted ramets of 4 cypress clones in all combinations. Self-rooted ungrafted ramets obtained from the 4 rootstock clones were used in the same test. All 4-year-old trees were measured for total height and diameter before artificial inoculation. Rootstock clones had no statistical influence on the diameter of grafted trees, but did significantly affect total height. Correlations among these growth traits and disease scores were non-significant. A statistically significant tendency for rootstocks to transfer their own canker susceptibility or resistance level to the grafted ramets did not, however, modify the resistance class into which the grafted clones had been previously classified.
\end{abstract}

\section{Cupressus sempervirens / bark canker disease / roostock effect}

Résumé - Effets du porte-greffe sur la réaction des cyprès greffés à la maladie du chancre cortical due à Seiridium cardinale. La connaissance des effets du porte-greffe sur la réaction des cyprès greffés à la maladie du chancre de l'écorce due à Seiridium cardinale, ainsi que la connaissance des paramètres de croissance des cyprès, pourraient jouer un rôle important dans la production de clones résistants. Des greffes (auto-, homo- et hétérogreffes) ont été réalisées à partir de rameaux enracinés de 4 clones de cyprès dans toutes les combinaisons. Les rameaux enracinés mais non greffés des 4 clones de porte-greffes ont été étudiés dans le même dispositif. Tous les arbres de 4 ans ont été mesurés pour leur hauteur et leur diametre avant inoculation artificielle. Les porte-greffes n'ont pas d'effet significatif sur le diametre, mais affectent significativement la hauteur des arbres greffés. Les corrélations entre caractères de croissance et gravité de la maladie n'étaient pas significatives. Une tendance, statistiquement significative, des porte-greffes à transférer leur propre sensibilité ou résistance au chancre aux greffons n'a pas modifié les classes de résistance dans lesquels les différents clones greffés avaient été préalablement placés.

Cupressus sempervirens / maladie du chancre cortical / effet du porte-greffe

Communicated by Jan Stenlid (Uppsala, Sweden)

* Correspondence and reprints

santini@ipaf.fi.cnr.it 


\section{Introduction}

Since ancient times, the Italian cypress (Cupressus sempervirens L.), has played a major role in the Mediterranean basin landscape. Its uses are three-fold: as an ornamental tree in parks and gardens, for afforestation purposes in poor calcareous soils, and as a wind-breaking barrier in agriculture. In recent decades, however, the cortical canker, caused by the deuteromycete Seiridium cardinale (Wag.) Sutton and Gibson, has caused serious damage throughout Europe, and fear for the future of the existing trees, making new cypress plantations inadvisable. For this reason, cypress improvement programs for resistance were set up with the attempt to cultivate resistant clones. Clones of Italian cypress, selected for resistance to $S$. cardinale, the pathogenic agent of cypress canker, are obtained vegetatively from grafts. Ramets of clones grafted onto seed-derived rootstocks usually maintain the growth vigor and crown shape of their ortet virtually unchanged, if grown in the same locality as the latter [8].

However, artificial inoculation tests on ramets of resistant and susceptible clones grafted onto seedlings have shown that some of these ramets (5-6\%) presented a symptomatology which differed from the expected outcome. These deviations could not be attributed to genotypic variation of the host and/or of the pathogen (as genetic mutations) or to a random effect due to their relatively high incidence. An explanation that the susceptibility found in ramets derived from resistant ortets and vice versa [4] could be due to the effect of the rootstock on epibiont response to disease progression should be evaluated.

The purpose of this study was to assess rootstock effects on cypress clone growth and reaction to bark canker, using auto-, homo- and heteroplastic grafts.

\section{Materials and methods}

Trials were begun in spring 1989, inducing the self-rooting of 500 cuttings for each of 4 clones
Table I. Clone codes and susceptibility degree. The degree of resistance/susceptibility was assessed in several different inoculation trials at various sites in Italy.

\begin{tabular}{|c|c|c|}
\hline Species & $\begin{array}{l}\text { Clone } \\
\text { code }\end{array}$ & $\begin{array}{l}\text { Degree of resistance/ } \\
\text { susceptibility }\end{array}$ \\
\hline C. sempervirens L. & \#276 & $\begin{array}{l}\text { Susceptible with a mean } \\
\text { disease score of } 2.5\end{array}$ \\
\hline C. sempervirens L. & \# 43 & $\begin{array}{l}\text { Resistant with a mean } \\
\text { disease score of } 1.6\end{array}$ \\
\hline C. goveniana Gordon & \#825 & $\begin{array}{l}\text { Intermediate with a mean } \\
\text { disease score of } 2.1\end{array}$ \\
\hline C. glabra Sudworth & \#308 & $\begin{array}{l}\text { Resistant with a mean } \\
\text { disease score of } 1.2\end{array}$ \\
\hline
\end{tabular}

with different levels of susceptibility/resistance to cortical canker (2 C. sempervirens L., 1 C. goveniana Gordon and 1 C. glabra Sudworth), previously evaluated for their degree of canker resistance in numerous inoculation trials at various locations in Italy (Tab. I), and chosen on this basis.

In January 1991, 645 self-rooted cuttings obtained from the ortets were grafted with the 4 clones considered in this study in all combinations. Fifty-five rooted cuttings were left ungrafted as a reference for the clone (Tabs. II and III).

Grafting procedures were based on the following definitions of auto-, homo- and heteroplastic grafts: i) autoplastic: grafting on a rootstock using scions taken from the actual rootstock itself or from ramets of the same variety of rootstock; ii) homoplastic: grafting on a rootstock using scions belonging to the same species as the rootstock; iii) heteroplastic: grafting on a rootstock using scions belonging to a different species.

In January 1993, successfully grafted trees and the self-rooted cuttings were transferred to the Monna Giovanella experimental farm (Antella, Florence), and planted at $2 \times 2 \mathrm{~m}$ intervals.

Prior to inoculation (December 1994), all 4-year-old trees were measured for total height and diameter at $20 \mathrm{~cm}$ above ground.

Inoculation was performed by drilling a $2-\mathrm{mm}$ hole in the bark [3], removing and replacing the bark with a mycelium disk of equal size collected 
Table II. For each rootstock clone, numbers and percentages referring to: scions to root, rooted scions obtained, grafted and self-rooted cypress trees transplanted in the field, and trees inoculated with $S$. cardinale mycelium $(\mathrm{Cgl}=$ Cupressus glabra; $\mathrm{Cs}=$ Cupressus sempervirens; $\mathrm{Cgo}=$ Cupressus goveniana $)$.

\begin{tabular}{|c|c|c|c|c|c|c|c|c|}
\hline \multirow[t]{2}{*}{ Rootstock } & \multicolumn{2}{|c|}{ Scions to root } & \multicolumn{2}{|c|}{ Rooted scions } & \multicolumn{2}{|c|}{ Grafted and self-rooted trees } & \multicolumn{2}{|c|}{ Inoculated ramets } \\
\hline & No. & $\%$ & No. & $\%$ & No. & $\%$ & No. & $\%$ \\
\hline $\mathrm{Cgl} \# 308$ & 500 & 100 & 250 & 50 & 230 & 46 & 148 & 29.6 \\
\hline Cs \# 43 & 500 & 100 & 115 & 23 & 115 & 23 & 67 & 13.4 \\
\hline Cgo \# 825 & 500 & 100 & 160 & 32 & 150 & 30 & 88 & 17.6 \\
\hline Cs \# 276 & 500 & 100 & 165 & 33 & 150 & 30 & 75 & 15.0 \\
\hline Total & 2000 & 100 & 690 & 34.5 & 645 & 32.2 & 378 & 18.9 \\
\hline
\end{tabular}

Table III. Number of inoculated trees transplanted in the field for each combination and, in parentheses, number of grafted rootstocks.

\begin{tabular}{lccccc}
\hline Rootstock & & \multicolumn{2}{c}{ Clone } & \multicolumn{2}{c}{ Self-rooted trees } \\
& $\# 308$ & $\# 43$ & \# & \#276 & \\
\hline$\# 308$ & $\mathbf{3 7 ( 5 0 )}$ & $\mathbf{1 5}(\mathbf{5 0})$ & $\mathbf{3 5}(\mathbf{5 0})$ & $\mathbf{3 5}(\mathbf{5 0})$ & $26(30)$ \\
$\# 43$ & $\mathbf{1 5}(\mathbf{2 5})$ & $\mathbf{1 0}(\mathbf{2 5})$ & $\mathbf{1 5}(\mathbf{2 5})$ & $9(20)$ & $18(20)$ \\
$\# 825$ & $\mathbf{2 5}(\mathbf{3 0})$ & $\mathbf{1 0}(\mathbf{3 0})$ & $\mathbf{2 5}(\mathbf{3 0})$ & $\mathbf{8}(\mathbf{3 0})$ & $20(30)$ \\
$\# 276$ & $\mathbf{1 5}(\mathbf{3 0})$ & $12(30)$ & $\mathbf{1 5}(\mathbf{3 0})$ & $\mathbf{1 1}(\mathbf{3 0})$ & $22(30)$ \\
Total & $92(135)$ & $47(135)$ & $90(135)$ & $63(130)$ & $86(110)$ \\
\hline
\end{tabular}

: autoplastic; bold: heteroplastic; italics: homoplastic grafts.

from the margins of a $S$. cardinale colony (isolate ATCC 38654). The inoculum was grown for 15 days on potato-dextrose agar (DIFCO, Detroit, MI, USA) at $25^{\circ} \mathrm{C}$. The inoculation site was then protected with adhesive tape. Each tree received only 1 inoculation, wherever possible on a north-facing site, where the trunk measured $1 \mathrm{~cm}$ in diameter. In order to verify that infection had successfully been induced, a first test was carried out 4-5 months following inoculation. All ramets were scored for canker severity at later stages.

Three years after inoculation (December 1997), each ramet was evaluated on the basis of host reaction to development of the pathogen. Reisolations were randomly performed in order to confirm the presence of $S$. cardinale in the infected tissues. To provide a complete description of the symptomatology, a rating scale was used for evaluating canker severity, ranging from score 1 to score 3 with 0.33 gradations $[3,5,6]$, where score 1 repre- sented complete compartmentalization of the canker and score 3 represented severe infection with expanding necrosis, resin exudation, fungus fructification, and frequently stem deformation. Intermediate points on the scale indicated intermediate levels of canker severity. No evaluation was made of any secondary infections present. Ramets with a mean disease score of $<1.66$ were considered resistant, ramets with a mean disease score of $\geq 2.66$ susceptible, and ramets with mean disease scores between these 2 values were considered to be intermediately resistant.

In the present study, the evaluation method of Andréoli et al. [1], based on the size of the necrotic imprint on the bark and on depth of pentetration into the wood, was not adopted. Andréoli's method, which is objective but also partially destructive, would not have allowed comparison of the disease score assigned in this trial with the mean score for each clone obtained in the different 
years and locations, nor a delineation of canker evolution over time.

Data were processed statistically by analysis of variance (ANOVA) using a fixed model. Whenever the $\mathrm{F}$ of ANOVA was found to be significant, Duncan's multiple-range test was adopted for assessment of significance among means at $\mathrm{P}=0.05$. The coefficent of variability $(\mathrm{CV})$ was calculated for total height and diameter.

\section{Results}

Only one-third of the cuttings (645 out of 2000 , corresponding to $32.2 \%$ ) could be used as a rootstock tree or rooted cutting (Tab. II). Out of these, only $378(18.9 \%)$ survived transplantation and were inoculated with $S$. cardinale for resistance evaluation. Table III also shows the number of grafted and inoculated cuttings for each combination. Rootstock \#43 showed poor rooting ability $(23 \%)$ with a low rate of successful grafting $(50 \%$, $\mathrm{n}=95$ ). Similar results were observed in rootstock \#276 (53 out of 120).

Table IV shows ANOVA results for the characters of epibiont vigor, height, diameter and response to inoculation in each ramet. Ungrafted trees obtained from rooted cuttings were not considered in this analysis, to avoid the effects of grafts on the data. Diameter was not influenced by

Table IV. Rootstock effects on vigor of grafted ramets (age: 4 years) and on cypress canker resistance measured 3 years after artificial inoculation (November 1997).

\begin{tabular}{lcccc}
\hline ANOVA & \multicolumn{4}{c}{ F values and significance } \\
& df & Height & $\begin{array}{c}\text { Diameter } \\
\text { Disease } \\
\text { score }\end{array}$ \\
\hline Among blocks & 15 & $24 * *$ & $1.38 \mathrm{~ns}$ & $45 * *$ \\
Among clones & 3 & $108^{* *}$ & $204 * *$ \\
Among rootstocks & 3 & $10 * *$ & $19 * *$ \\
$\begin{array}{l}\text { Interaction } \\
\text { clones } \times \text { rootstocks }\end{array}$ & 9 & $<1 \mathrm{~ns}$ & $<1 \mathrm{~ns}$ \\
Error & 276 & & \\
\hline
\end{tabular}

** Significant at the $1 \%$ level; ns: not significant. the rootstock or grafted clone (Tab. IV). In contrast, the characters of tree height and canker resistance were significantly affected by the rootstock and grafted clone, although the effect of the clone $\times$ rootstock interaction was non-significant (Tab. IV).

The main objective of the study was to assess the rootstock effect on each of the 4 grafted clones. Consequently, the ANOVA carried out on each epibiont clone, including the self-rooted trees, for the characters of height, diameter and disease score assumed greater importance than the ANOVA for all the combinations. CVs obtained were generally rather low for field tests, confirming sample and experimental design validity.

Table V lists mean values and CVs for height, diameter and disease score of the 4 grafted clones and self-rooted trees. Letters are used to distinguish the homogeneous groups obtained by Duncan's test.

No statistical difference in diameter was found among the 4 grafted clones, and CVs were likewise low. The different clones also showed no differences in diameter when different rootstocks were used, with the range of variation lying between 13.8 and $15.6 \mathrm{~cm}$.

Height was consistently lower in self-rooted than in grafted trees. Clone \#276 presented the highest and most homogeneous values. Clone \#825 was variable, but differences were not significant when it was grafted onto $C$. sempervirens. Differences in clones \#43 and \#308, which were highlighted in Duncan's tests, had no clear biological explanation. In general, rootstock 276 was always linked to the greatest height values.

Rootstocks had a statistically significant effect on the susceptibility/resistance effect of the scions.

The highest mean disease score was recorded for self-rooted clone \#276. Clone \#276 always exhibited the highest mean disease score in each combination, but with no significant difference. When this clone was used as a rootstock, for clones \#308 and \#825, this resulted in a significantly higher mean disease score as compared to values obtained when these clones were grafted onto other rootstocks. 
Table V. For each combination: $\mathrm{N}=$ number of inoculated ramets; $\mathrm{H}=$ mean height in $\mathrm{cm} ; \mathrm{D}=$ mean diameter in mm (in italics: CV = coefficient of variability) measured in 4-year-old trees; DS = mean disease score 3 years after inoculation (November 1997). ANOVA was carried out for each grafted clone separately (Duncan's multiple range test was used when the F of ANOVA was significant; the same letters indicate no significant difference among means on the same line at $\mathrm{P}=0.05$ ).

\begin{tabular}{|c|c|c|c|c|c|c|}
\hline \multirow[t]{2}{*}{ Scion } & & \multicolumn{4}{|c|}{ Rootstock } & \multirow[t]{2}{*}{ Self-rooted trees } \\
\hline & & \# 308 & \# 43 & \# 825 & \# 276 & \\
\hline \multirow[t]{6}{*}{ \# 308} & $\mathrm{~N}$ & 37 & 15 & 25 & 15 & 26 \\
\hline & $\mathrm{H}$ & $176.0 \mathrm{c}$ & $170.2 \mathrm{~b}$ & $169.5 \mathrm{~b}$ & $179.4 \mathrm{c}$ & $158.3 \mathrm{a}$ \\
\hline & $C V$ & 8.8 & 9.3 & 9.8 & 9.3 & 7.6 \\
\hline & $\mathrm{D}$ & 15.2 & 14.7 & 15.6 & 15.4 & 14.3 \\
\hline & $C V$ & 5.4 & 5.5 & 5.4 & 5.6 & 3.8 \\
\hline & DS & $1.02 \mathrm{a}$ & $1.04 \mathrm{a}$ & $1.10 \mathrm{a}$ & $1.22 \mathrm{~b}$ & $1.10 \mathrm{a}$ \\
\hline \multirow[t]{6}{*}{ \# 43} & $\mathrm{~N}$ & 15 & 10 & 10 & 12 & 18 \\
\hline & $\mathrm{H}$ & $145.4 \mathrm{~b}$ & $151.5 \mathrm{bc}$ & $154.5 \mathrm{bc}$ & $157.2 \mathrm{c}$ & $134.8 \mathrm{a}$ \\
\hline & $C V$ & 11.0 & 9.1 & 8.9 & 8.8 & 7.3 \\
\hline & D & 14.3 & 14.8 & 15.0 & 15.0 & 14.4 \\
\hline & $C V$ & 4.3 & 4.7 & 4.4 & 4.2 & 3.9 \\
\hline & DS & $1.06 \mathrm{a}$ & $1.09 \mathrm{a}$ & $1.48 \mathrm{~b}$ & $1.53 \mathrm{~b}$ & $1.15 \mathrm{a}$ \\
\hline \multirow[t]{6}{*}{ \# 825} & $\mathrm{~N}$ & 35 & 15 & 25 & 15 & 20 \\
\hline & $\mathrm{H}$ & $165.2 \mathrm{a}$ & $172.4 \mathrm{~b}$ & $180.3 \mathrm{c}$ & $173.3 \mathrm{~b}$ & $161.7 \mathrm{a}$ \\
\hline & $C V$ & 6.9 & 8.4 & 9.4 & 8.0 & 8.2 \\
\hline & D & 14.1 & 14.6 & 14.5 & 14.5 & 14.4 \\
\hline & $C V$ & 2.6 & 4.3 & 4.6 & 4.5 & 4.7 \\
\hline & DS & $1.81 \mathrm{a}$ & $1.80 \mathrm{a}$ & $1.90 \mathrm{a}$ & $2.34 \mathrm{~b}$ & $2.00 \mathrm{a}$ \\
\hline \multirow{6}{*}{ \# 276} & $\mathrm{~N}$ & 35 & 9 & 8 & 11 & 22 \\
\hline & $\mathrm{H}$ & $182.3 \mathrm{a}$ & $179.5 \mathrm{a}$ & $186.1 \mathrm{a}$ & $185.9 \mathrm{a}$ & 164.1 \\
\hline & $C V$ & 7.5 & 10.4 & 11.1 & 11.3 & 7.9 \\
\hline & $\mathrm{D}$ & 14.9 & 15.1 & 15.3 & 15.1 & 13.8 \\
\hline & $\mathrm{CV}$ & 3.9 & 4.4 & 5.3 & 2.6 & 4.5 \\
\hline & DS & $2.00 \mathrm{a}$ & $2.00 \mathrm{a}$ & $2.15 \mathrm{a}$ & $2.40 \mathrm{~b}$ & $2.50 \mathrm{~b}$ \\
\hline
\end{tabular}

Similarly, the resistant clone \#43 grafted onto clone \#276 produced a statistically different mean disease score in comparison to that observed when rootstocks \#308 and \#43 or self-rooted trees were used, but this difference was not found with rootstock \#825. On the other hand, ramets of clone \#276 presented lower mean disease scores when the resistant rootstocks \#308, \#43 and the intermediate resistance clone \#825 were used, as compared to scores recorded with the susceptible rootstock \#276 and rooted cuttings. The lowest disease score was shown by auto-plastic grafted \#308, which consistently had a lower disease score than the others in all combinations.
Correlations between disease score and height $\left(\mathrm{r}^{2}=0.15\right)$, and between disease score and diameter $\left(r^{2}=0.18\right)$, were not significant.

\section{Discussion}

The INRA research unit (Antibes) was entrusted with studying the effects of homoplastic grafting on grafted clone growth and reaction to $S$. cardinale. The results have been published recently [1]. These authors found that the rootstock had no noticeable effect on the basic behavior of scions, 
but the reaction of resistant clones to disease and scarring varied according to the degree of susceptibility/resistance of the rootstock clone. Moreover, they reported that resistance was basically related to vigor conferred to scions by the roootstock. Readers are referred to this publication, and the bibliography contained therein concerning rootstock effects on scion susceptibility to disease. The references are particularly numerous in the section on arboriculture, above all as regards fruit-tree growing and production. Studies available on the relation between rootstock and resistance focus mainly on pathologies in which the rootstock acts as host $[2,12]$. However, in the case of some phytoplasmal diseases it has been found that rootstocks which tolerate or resist phytoplasmal infection can reduce symptom severity in susceptible scions of some fruit trees $[13,14]$ In ash yellows, diseased white ash scions (less tolerant) on velvet ash (more tolerant) roots sustained significantly less growth suppression than did diseased selfrooted white ash [11]. For cypress, to our knowledge this interaction was not described prior to the above-quoted work by Andréoli et al. [1].

Reciprocal grafting and self-rooting of $2 \mathrm{C}$. sempervirens, 1 C. glabra and 1 C. goveniana clone demonstrated that the rootstock effects are merely modulations of the 'canker resistance' character, which is basically under polygenic control [7], and confirmed the results of Andréoli et al. [1] obtained through homoplastic grafts.

However, a statistically significant trend was detected for the rootstock to transfer its own level of canker susceptibility to the grafted scion, leading to variations in the mean disease score without modifying the resistance class to which the clone had been assigned in previous tests.

From a technical-operational point of view, it may be hypothesized that the roostock does not modify the 'qualitative' response of the ortet to $S$. cardinale attack. For example, clone \#308, which is resistant with a disease score of 1.2 , presented a very low disease score (1.08) for the 118 ramets used in this trial independently of the rootstock utilized, including the rooted cuttings. The same considerations can be made for the susceptible clone \#276.
Analysis of ramet vigor, i.e., diameter and height growth, suggested that the 4 rootstocks did not induce a significant increase in scion diameter, whereas they did at times have a significant effect on height. These results are partially in accordance with the findings reported by Andréoli et al. [1], which indicated that vigorous rootstocks, especially clone \#42S (C. sempervirens), transmitted greater vigor to the scion itself, and thereby significantly favored canker compartmentalization. The above authors offer the plausible explanation that the vigor transferred to the scion by the rootstock could promote anatomical defense processes. In contrast to these findings, our results demonstrated that the clone with the highest mean height was the most susceptible to the disease.

The absence of significant correlations between disease score and height and diameter suggests that the character of canker resistance is inherent to the ortet and is influenced only slightly by factors acting directly or indirectly on ramet vigor. However, Santini et al. [9, 10] demonstrated experimentally that the environmental effect plays an important role in the disease level of an ortet; and that obtaining universally resistant cypress clones, i.e., clones that show a stable disease resistance in the majority of environments, is a highly complex process.

Within a given ortet, trees obtained from homospecific grafts showed no substantial differences in height and diameter as compared to trees from heteroplastic grafts. Finally, self-rooted ungrafted trees showed lower vigor up to the age of 4 years as compared to cypresses obtained from homo- and heteroplastic grafts, but had a mean disease score that generally did not differ from scores recorded on auto-, homo- and heteroplastic grafts.

In conclusion, grafting vegetative propagation of cypress can continue to be the method most widely used in nurseries for large-scale production of resistant material. The results of this study and the data of Andréoli et al. [1] suggest that the most suitable rootstocks are constituted by canker-resistant clones multiplied by rooted cutting. Such selected rootstock clones must also display marked rhizogenous ability and pronounced graft affinity. 
It thus seems possible, and desirable in the case of $C$. glabra clone \#308, to use species other than $C$. sempervirens to constitute rootstocks for common cypress. However, there is a need for further assessment of large-scale utilization of rootstocks propagated vegetatively from cuttings, since few studies have been conducted so far to consider whether clonal and self-rooted rootstocks offer genuine economic advantages in nursery production as compared to the use of seedlings grown from commercial seed. Future research should also determine the stability offered by the self-rooted rootstock in different soils and the adaptive response to root pathogens by rootstocks obtained from rooted cuttings.

Acknowledgements: This study was carried out within the framework of the EC-funded Camar and AirCypress research projects.

\section{References}

[1] Andréoli C., Ponchet J., Mari E., Effects du portegreffe sur la réaction du cyprès à la maladie du chancre cortical à Seiridium cardinale, Agronomie 16 (1996) 563-571.

[2] Bielenin A., Phytophtora crown rot of apple trees: influence of the scion cultivar on rootstock susceptibility, J. Fruit Ornam. Plant Res. 3 (1995) 53-60.

[3] Panconesi A., Casini N., Santini A., Stefanini F.M., Effect of Seiridium cardinale on growth of cypress (Cupressus sempervirens) clones, Can J. For. Res. 25 (1995) 109-113.

[4] Raddi P., Breeding strategy for cypress canker disease, in: Proc. IUFRO Conf.: Joint Meeting of Working Parties on Breeding Theory, Progeny Testing, Seed Orchards, Williamsburg, USA, 1986, pp. 334-341.

[5] Raddi P., Panconesi A., Pathogenicity of some isolates of Seiridium (Coryneum) cardinale, agent of cypress canker disease, Eur. J. For. Pathol. 14 (1984) 348-354.

[6] Raddi P., Panconesi A., Di Lonardo V., Miglioramento genetico del cipresso per la resistenza al cancro, in: P. Raddi (Ed.), Maladie du cyprès, Rep. EUR 9200 (1984) 41-46.

[7] Raddi P., Panconesi A., Xenopoulos S., Ferrandes P., Andréoli C., Genetic improvement for resistance to canker disease, in: J. Ponchet (Ed.), Progress in EEC Research on Cypress Diseases, Rep. EUR 12493 (1990) 26-28.

[8] Santini A., Casini N., Panconesi A., Di Lonardo V., Effetto dell'ambiente sulla morfologia e sulla crescita di alcuni cloni di Cupressus sempervirens e possibili relazioni con Seiridium cardinale, 3 (1994) 42-48.

[9] Santini A., Casini N., Panconesi A., Di Lonardo V., Nembi V., Risposte comparative all'infezione con Seiridium cardinale in due località italiane. L'Italia Forestale e Montana 4 (1994) 389-400.

[10] Santini A., Casini N., Di Lonardo V., Raddi P., Canker resistance stability of some Cupressus sempervirens clones to Seiridium cardinale, J. Genet. Breed. 51 (1997) 269-277.

[11] Sinclair W.A., Griffiths H.M., Comparisons of tolerance of ash yellows phytoplasmas in Fraxinus species and rootstock-scion combinations, Plant Dis. 81 (1997) 395-398.

[12] Smit W.A., Viljoen C.D., Wingfield B.D., Wingfield M.J., Calitz F.J., A new canker disease of apple, pear, and plum rootstocks caused by Diaporthe ambigua in South Africa, Plant Dis. 80 (1996) 1331-1335.

[13] Westwood M.N., Lombard P.B., Pear rootstocks: present and future, Fruit Var. J. 37 (1983) 24-28.

[14] Westwood M.N., Cameron H.R., Lombard P.B., Cordy C.B., Effects of trunk and rootstock on decline growth and performance of pear, J. Am. Soc. Hortic. Sci. 96 (1971) 147-150. 